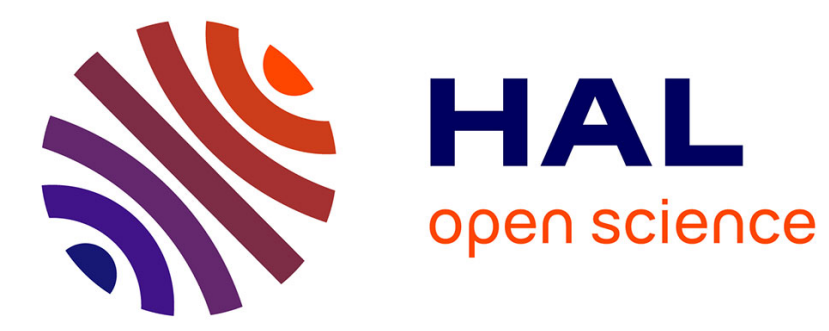

\title{
Photorefractive laser beam modulator
}

\author{
R. Müller, J. Alvarez, L. Arizmendi, J. Cabrera
}

\section{To cite this version:}

R. Müller, J. Alvarez, L. Arizmendi, J. Cabrera. Photorefractive laser beam modulator. Journal de Physique IV Proceedings, 1994, 04 (C4), pp.C4-596-C4-596. 10.1051/jp4:19944147 . jpa-00252602

\section{HAL Id: jpa-00252602 https://hal.science/jpa-00252602}

Submitted on 1 Jan 1994

HAL is a multi-disciplinary open access archive for the deposit and dissemination of scientific research documents, whether they are published or not. The documents may come from teaching and research institutions in France or abroad, or from public or private research centers.
L'archive ouverte pluridisciplinaire HAL, est destinée au dépôt et à la diffusion de documents scientifiques de niveau recherche, publiés ou non, émanant des établissements d'enseignement et de recherche français ou étrangers, des laboratoires publics ou privés. 


\title{
Photorefractive laser beam modulator
}

\author{
R. MÜLLER, J.V. ALVAREZ, L. ARIZMENDI and J.M. CABRERA
}

Universidad Autónoma de Madrid, Depto. Física de Materiales C-IV, Canto Blanco, 28049 Madrid, Spain

A new laser beam modulator is demonstrated using both photorefractive and piezoelectric properties of $\mathrm{LiNbO}_{3}$. It is based on a narrow bandwidth Bragg reflector interference filter previously developed in $\mathrm{LiNbO}_{3}$ by photorefractive fixing of a volume hologram. The filter performances for a $2 \mathrm{~mm}$ thick plate and a writing wavelength of $514.5 \mathrm{~nm}$ are the following: a FWHM bandwidth of $50 \mathrm{pm}$, a peak reflectivity of $32.5 \%$ and an angular field of view of $4^{\circ}$ at a peak wavelength of $518.45 \mathrm{~nm}$. The peak wavelength of the Bragg reflector can be tuned by applying an electric field to the large plate surfaces. By piezoelectric effect the period of the hologram grating can be changed so that the Bragg angle is also varied. This allows a peak tunability of about 10 $\mathrm{pm} / \mathrm{kV}$ which corresponds to about a quarter of FWHM per kilovolt. Temperature can also be used in the same way giving a tunability of about 2.5 $\mathrm{pm} / \mathrm{K}$. By applying an $\mathrm{AC}$ electric field the on/off-Bragg condition produces a modulating effect on the reflected beam. A modulation depth of about $80 \%$ has been demonstrated using a $\pm 2 \mathrm{kV}$ voltage on our sample. Further improvements in the fabrication procedure of the filter and the optimization of the geometry of the sample are expected to increase the modulation capabilities and reduce the required voltage. 